\title{
Pengaruh Diet Sodium dan Pembatasan Cairan Berbasis Aplikasi Android Terhadap Keseimbangan Cairan Dan Dyspnea Pada Pasien Gagal Jantung Kongestif $(\mathrm{CHF})$
}

\author{
Agus Putradana ${ }^{1}$, Muh.Mardiyono ${ }^{2}$, Nana Rochana ${ }^{3}$ \\ ${ }^{1}$ Prodi S1 Keperawatan, Sekolah Tinggi Ilmu Kesehatan (STIKES) Mataram, \\ ${ }^{2}$ Poltekkes Kemenkes Semarang, ${ }^{3}$ Universitas Diponegoro \\ Email Korespondensi:putradanaagus@gmail.com
}

\begin{abstract}
Abstrak. Pembatasan cairan dan Diet sodium merupakan salah satu terapi non-farmakologis yang dilakukan bagi penderita Gagal Jantung Kongestif NYHA II dengan gejala dyspnea. Munculnya gejala sesak nafas pada penderita gagal jantung, disebabkan oleh terjadinya ketidak seimbangan cairan tubuh pasien, yang mengakibatkan menumpuknya cairan pada jaringan paru-paru (kongesti pulmonal). Pembatasan cairan dan diet sodium menjadi terapi nonfarmakologis utama bagi pasien penderita gagal jantung. Beberapa pasien melaporkan menjalani kesulitan dalam melakukan control dan pencatatan konsumsi cairan, konsumsi sodium, serta gejala dyspnea yang muncul. Oleh karena itu, dibutuhkan suatu penanganan yang dapat memfasilitasi pasien dalam melakukan control konsumsi cairan, konsumsi sodium serta pencatatan gejala dyspnea yang muncul yang berakibat pada tidak tercapainya keseimbangan cairan dan munculnya gejala dyspnea. pembatasan cairan dan diet sodium berbasis aplikasi merupakan intervensi pilihan dan aman dilakukan untuk mencegah terjadinya ketidakseimbangan cairan tubuh dan munculnya gejala dyspnea. Tujuan: Mengidentifikasi pengaruh Pembatasan cairan dan Diet sodium berbasis aplikasi android terhadap perbaikan keseimbangan cairan dan penurunan gejala dyspnea pada pasien gagal jantung kongestif. Metode: Desain penelitian quasy eksperimen, dengan menggunakan simple random sampling, 40 orang kelompok intervensi dan 40 orang kelompok kontrol, dengan analisis uji Chi-square, Wilcoxon dan Mann Whitney. Hasil: Hasil penelitian menunjukkan ada perbaikan keseimbangan cairan $(\mathrm{p}=0.001)$, dan penururnan gejala dyspnea $(\mathrm{p}=0.001)$. Kesimpulan: Terdapat pengaruh Pembatasan Cairan dan Diet Sodium berbasis aplikasi android terhadap perbaikan keseimbangan cairan dan penurunan gejala dyspnea pada pasien gagal jantung kongestif NYHA II. Intervensi diet sodium dan pemabatasan cairan berbasis aplikasi android ini merupakan intervensi yang mudah digunakan serta sangat bermanfaat untuk dilakukan bagi pasien gagal jantung kongestif NYHA II.
\end{abstract}

Keywords: Pembatasan cairan, diet sodium, aplikasi android, keseimbangan cairan, dyspnea

\begin{abstract}
Fluid restriction and sodium diet is one of the non-pharmacological therapies performed for people with Congestive Heart Failure NYHA II. During the therapy process, complaints of dyspnea often arise which are the main symptoms in patients with congestive heart failure. The appearance of symptoms of shortness of breath in patients with heart failure is caused by an imbalance in the patient's body fluids, which results in accumulation of fluid in the lung tissue (pulmonary congestion). Sodium diet and fluid restriction is the main non-pharmacological therapy for patients with heart failure. Some patients report having difficulty controlling and recording fluid consumption, sodium consumption, and symptoms of dyspnea that appear. Therefore, a treatment is needed to facilitate the patient in controlling fluid consumption, consumption of sodium and recording symptoms of dyspnea. Fluid restriction and sodium diets based on android application are the preferred and safe intervention to prevent imbalance in body fluids and the appearance of symptoms of dyspnea. Objective: To identify the effect of fluid restriction and sodium diet based on android applications to improve fluid balance and decrease symptoms of dyspnea in congestive heart failure patients. Methods: The design of the research was quasy experiment, using simple random sampling, 40 people in the intervention group and 40 people in the control group, with the analysis method was Chi-square, Wilcoxon and Mann Whitney test. Results: The results showed that there was an improvement in fluid balance $(p=0.001)$, and deterioration of symptoms of dyspnea $(p=0.001)$. Conclusion: There is effect of Fluid Limitation and Sodium Diet based on android application to improve fluid balance and decrease symptoms of dyspnea in congestive heart failure NYHA II patient. This combination of fluid restriction and sodium diet based on this android application is applicable and effective, and it is an easy-to-use and very useful intervention for congestive heart failure NYHA II patient.
\end{abstract}

Keywords: Fluid restriction, sodium diet, android application, fluid balance, dyspnea

\section{PENDAHULUAN}

Gagal Jantung Kongestif atau Congestive Heart Failure $(\mathrm{CHF})$ adalah keadaan di mana jantung tidak mampu memompa darah untuk mencukupi kebutuhan jaringan dalam melakukan metabolisme. ${ }^{1} \mathrm{CHF}$ timbul akibat kelainan struktur dan fungsi jantung. ${ }^{2,3}$ Penyakit ini menjadi penyebab kematian 
nomor satu di dunia, sebanyak 17,5 juta jiwa kematian di dunia disebabkan oleh penyakit jantung. Angka tersebut diproyeksikan akan tetap meningkat sampai tahun 2030, diperkirakan 23,6 juta jiwa penduduk akan meninggal akibat penyakit jantung diseluruh dunia. $^{4}$ Masalah tersebut juga menjadi masalah kesehatan yang progresif dengan angka mortalitas yang tinggi di Indonesia. Indonesia menduduki peringkat kedua di Asia Tenggara dengan jumlah 371 ribu jiwa. ${ }^{4}$ Hasil Riset Kesehatan Dasar Kemenkes RI tahun 2013 menunjukan angka kejadian gagal jantung di provinsi Nusa Tenggara Barat mencapai angka 353.378 jiwa. Hasil studi pendahuluan di Rumah Sakit Umum Provinsi Nusa Tenggara Barat didapatkan data jumlah penderita $C H F$ yang dirawat pada tahun 2015 dan 2016 tanpa penyakit penyerta selain penyakit pernafasan sebanyak 250 pasien.

Gagal Jantung Kongestif merupakan penyakit yang menimbulkan gejala yang bersifat sistemik. Kegagalan jantung dalam memompa darah dapat mengakibatkan retensi cairan pada pasien $C H F$. ${ }^{4}$ Retensi cairan yang terjadi selanjutnya mengakibatkan cairan tubuh berada dalam keadaan tidak seimbang. Penumpukan yang terjadi pada paru-paru dapat meningkatan tekanan vaskular pulmonal. ${ }^{1,5}$ Keadaan ini menimbulkan gejala khas yaitu sesak napas atau dyspnea baik saat beraktifitas maupun pada saat beristirahat. ${ }^{6,7}$

Keseimbangan cairan dan sesak nafas merupakan masalah keperawatan utama yang dialami pasien $\mathrm{CHF} .{ }^{10}$ Penelitian Tertius dan Peacock IV menyebutkan dyspnea merupakan gejala utama yang diungkapkan pasien $\mathrm{CHF}$ dengan pravelensi lebih dari $90 \% .{ }^{11}$ Dyspnea pada pasien gagal jantung menjadi salah satu faktor utama yang menyebabkan pasien $\mathrm{CHF}$ menjalani rawat ulang di rumah sakit. ${ }^{13}$

Penatalaksanaan yang tepat serta discharge planning terkontrol efektif terhadap peningkatan kapasitas fungsional akan menurunkan rawat inap ulang pada pasien dengan $\mathrm{CHF}^{14}$ Banyak faktor yang mengakibatkan ganguan keseimbangan cairan dan elektrolit, diantaranya yaitu usia, diet, dan aktifitas. ${ }^{15}$
Penatalaksanaan bagi pasien dengan $C H F$ terbagi menjadi dua yaitu secara farmakologis dan nonfarmakologis. Terapi farmakologis misalnya dengan penggunaan obat duiretik, glikosida digitalis, vasodilator, sedangkan terapi nonfarmakologis yaitu pembatasan aktivitas sesuai beratnya keluhan, diet rendah garam, mengurangi berat badan, mengurangi lemak, mengurangi stress psikis, menghindari rokok, olahraga teratur dan mengatur konsumsi cairan sesuai dengan program diet. ${ }^{16,17}$

Program diet yang diterapkan diantaranya diet sodium dan cairan, yang merupakan metode diet sebagai terapi nonfarmakologis utama yang dapat dilakukan saat ini. Intervensi dengan perpaduan diet sodium serta pembatasan asupan cairan menunjukkan hasil yang baik pada penanganan pasien dengan $C H F$. Penatalaksanaan diet dan pendidikan kesehatan yang dilakukan pada saat perawatan di rumah sakit sering tidak berkelanjutan, hal ini disebabkan karena pasien tidak memiliki alat bantu atau support dalam meneruskan program tersebut.

Penggunaan teknologi pada pasien $\mathrm{CHF}$ terutama dengan masalah keseimbangan cairan dan dyspnea akan membantu dalam perhitungan jumlah diet sodium dan pembatasan cairan yang dibutuhkan untuk dikonsumsi. Saat ini belum ada aplikasi untuk memonitor keseimbangan cairan baik intake dan output.

Intervensi baru yang ditawarkan oleh peneliti untuk membantu diet sodium dan pembatasan cairan adalah penggunaan teknologi dengan memanfaatkan aplikasi android. Penggunaan aplikasi android sebagai sarana untuk memberikan informasi kepada pasien dapat memudahkan dalam hal mencari informasi yang dibutuhkan di jaman modern ini, hal ini didukung oleh teori TAM (Technology Acceptance Model) yang mengatakan bahwa seseorang dapat dipengaruhi dan menerima adanya sistem informasi dengan menggunakan tekhnologi. ${ }^{24}$

Intervensi ini disebut aplikasi diet sodium dan pembatasan cairan. Aplikasi ini akan membantu pasien dalam mengontrol pemasukan sodium dan cairan, memberikan 
reminder pada pasien terkait pemasukan sodium dan cairan, dan memberikan edukasi terkait diet sodium dan pembatasan cairan pasien $\mathrm{CHF}^{25}$

Program ini terdiri dari 5 menu utama yaitu data dasar tentang kebutuhan cairan, pengontrolan pemasukan cairan dan sodium, pemantauan keseimbangan cairan, tips kesehatan berkaitan dengan pengontrolan cairan, dan grafik pencapain diet cairan dan sodium. Aplikasi ini merupakan jawaban dari beberapa hambatan yang dialami oleh pasien khususnya pada faktor self-assesment, dimana pasien dapat menentukan status diet sodium dan pembatasan cairan secara keseluruhan.

Program ini juga menjawab tentang hambatan pasien mengenai faktor pengetahuan, dimana dalam aplikasi ini terdapat menu yang berisi pemberian edukasi pada pasien. Intervensi ini juga menjawab teori seft-care yang menyebutkan bahwa orang mempunyai kemampuan dasar (natural ability) untuk melakukan perawatan diri (self care) dan perawat harus fokus untuk mempengaruhi kemampuan tersebut. ${ }^{23}$

\section{METODE PENELITIAN}

Penelitian ini merupakan jenis penelitian kuantitatif experiment design. Penelitian ini bertujuan untuk mengungkapkan kemungkinan adanya pengaruh aplikasi diet sodium dan pembatasan cairan terhadap keseimbangan cairan dan dyspnea pada pasien CHF. Rancangan penelitian ini dengan membagi sampel menjadi 2 kelompok yaitu kelompok kontrol dan kelompok perlakuan atau intervensi. Pada kelompok kontrol maupun intervensi sama sama memperoleh perawatan dan tindakan medik sesuai prosedur rumah sakit. Khusus pada kelompok intervensi diberikan aplikasi diet sodium dan pembatasan cairan selama 7 hari di rumah yang kemudian didilakukan follow up (post test). Pada kedua kelompok tersebut dilakukan observasi nilai keseimbangan cairan dan dyspnea selama penelitian. Pengukuran dilakukan sebelum pemberian intervensi (pre test) dan setelah pemberian intervensi (post test).
Populasi dalam penelitian ini adalah semua pasien $\mathrm{CHF}$ di poli penyakit dalam RSUP Mataram. Teknik sampling dalam penelitian ini adalah simple random sampling dengan klasifikasi grade $C H F$ NYHA II. Randomisasi alokasi sebagai kelompok kontrol dan intervensi menggunakan amplop dengan cara mengambil amplop yang bertuliskan angka ganjil (1) untuk kelompok kontrol dan angka genap (2) untuk kelompok intervensi. Sampel minimal yang dibutuhkan dalam penelitian berjumlah 80 responden, sehingga untuk masing-masing kelompok adalah 40 responden.

Aplikasi Diet sodium dan pembatasan cairan adalah Intervensi dengan bantuan aplikasi yang digunakan dalam mengikuti diet sodium (2-3 mg) dan pembatasan cairan (800$1000 \mathrm{ml}$ ) sesuai dengan rekomendasi pemberi pelayanan kesehatan selama 7 hari.

Alat ukur yang digunakan dalam penelitian ini adalah:

1) Kuesioner data karakteristik responden.

Instrumen untuk data karakteristik responden diisi oleh peneliti dari data rekam medis pasien yaitu nama responden (inisial), jenis kelamin, usia, klasifikasi NYHA, lama menderita $C H F$.

2) Kuesioner Medical Research Council (MRC)

Merupakan kuesioner yang mengukur sesak nafas terdiri atas 5 kategori. Kuesioner ini dibuat berdasarkan satu pandangan tentang tindakan yang bisa menimbulkan sesak nafas seperti berjalan. Langkahnya adalah mengukur skala dyspnea pada pasien yang terdiri dari skala $0 ; 1 ; 2 ; 3$; dan 4. Skala terendah adalah 0 dan skala tertitnggi adalah 4, yang dilakukan dengan wawancara dan mengisi kuesioner. Kuesioner ini telah dipakai pada penelitian sebelumnya tentang dyspnea pada pasien PPOK. Instrumen ini diisi oleh peneliti.

3) Keseimbangan cairan

Perhitungan keseimbangan cairan membutuhkan data berupa asupan dan keluaran. Keseimbangan cairan dihitung dengan rumus balance cairan=intake 
cairan-output cairan (normal balance cairan $\pm 100 \mathrm{cc})$. Akumulasi cairan yang dianggap normal atau seimbanga adalah hasil pengukuran antara $-100 \mathrm{cc}$ sampai +100 cc. Pada kelompok Intervensi pencatatan dan perhitungan keseimbangan cairan dilakukan pada aplikasi sedangkan pada kelompok kontrol pencatatan dilakukan secara manual pada kuesioner yang telah disediakan. Pengisian data (proses input) diawasi oleh enumerator sehingga dapat dipastikan responden melakukan pengisian data sesuai dengan kebutuhan.

4) Smartphone dimana didalamnya berisi aplikasi yang terdiri dari 5 menu utama yaitu data dasar tentang kebutuhan cairan, pengontrolan pemasukan cairan dan sodium, pemantauan konsumsi cairan dan sodium harian, tips kesehatan berkaitan dengan pengontrolan cairan, dan grafik pencapain diet cairan dan sodium. Menu pertama terdiri dari data pasien yang dimana jika data diisikan maka akan muncul jumlah sodium dan cairan yang bisa dikonsumsi oleh pasien. Menu kedua merupakan menu kontrol sodium dan cairan, menu ini berisi data jumlah sodium dan cairan yang dikonsumsi pasien. Pemasukan konsumsi sodium dan cairan, dimana pasien harus mengisi berapa gram sodium dan berapa $\mathrm{ml}$ cairan yang telah dikonsumsi, kemudian akan muncul berapa gram sodium dan berapa volume cairan lagi (milliliter) yang boleh dikonsumsi pasien, sehingga pasien mampu mengontrol atau mengkalkulasi pemasukan sodium dan cairan pasien. Jumlah sodium dan cairan pasien tersisa $15 \%$ maka akan muncul alarm nada di smartphone klien. Menu ketiga terdiri dari nutrition calculation yaitu untuk mengukur kadar sodium dan cairan pada bahan makanan yang akan dikonsumsi oleh pasien sehingga pasien dapat menentukkan dan mengantisipasi jumlah sodium dan cairan pada makanana yang akan dipilih. Menu keempat yaitu grafik pencapaian diet yaitu memperlihatkan grafik pencapaian diet pasien. Menu kelima yaitu berisi tips dan edukasi terkait pembatasan sodium dan cairan.

Analisa data untuk menguji keseimbangan cairan dan Dyspnea post intervensi pasien $\mathrm{CHF}$ pada kelompok kontrol dan kelompok intervensi menggunakan Uji Mann-Whitney. Uji tersebut untuk menentukkan adanya pengaruh atau tidak dari intervensi yang diberikan.

\section{HASIL PENELITIAN}

Penelitian dilakukan kepada pasien $C H F$ NHYA II di RSUD Provinsi NTB dengan 40 responden pada masing-masing kelompok kontrol dan intervensi. Hasil penelitian terdiri dari data karakteristik responden, keseimbangan cairan, dan pengaruh intervensi terhadap dyspnea.

\section{Karakteristik Responden}

Data karakteristik responden disajikan dalam bentuk tabel yang terdiri dari frekuensi dan mean. Data dikelompokkan berdasarkan usia, jenis kelamin, pendidikan, lama terdiagnosa menderita $C H F$. Homogenitas karakteristik responden dapat diketahui dengan uji chi-square. Karakteristik dan homogenitas pada kelompok intervensi dan kontrol tergambar pada tabel 8 .

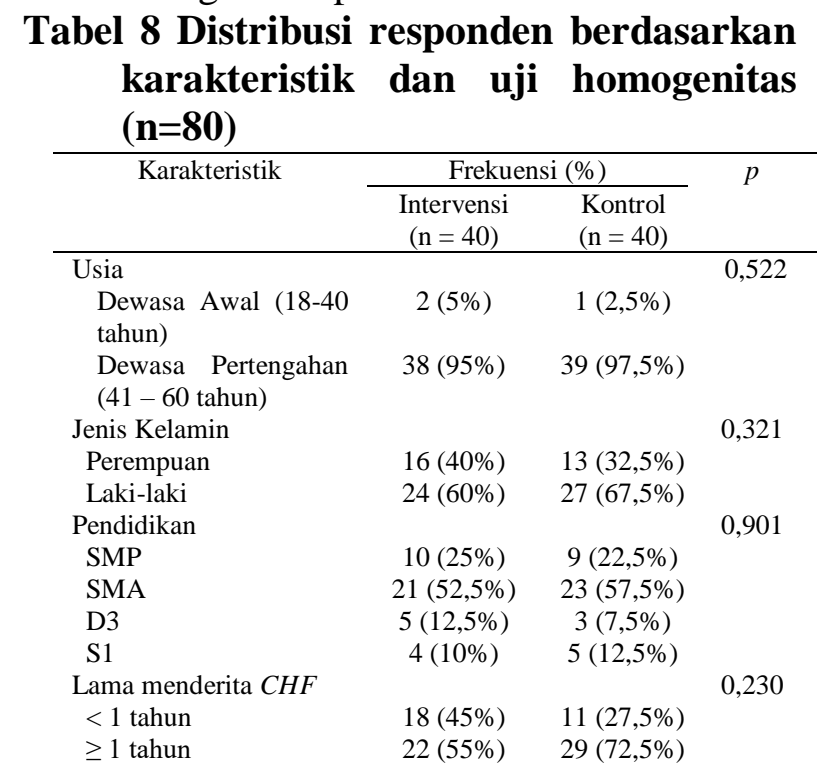

Tabel 8 menunjukkan bahwa sebagian besar usia pada kelompok intervensi dan kelompok kontrol adalah dewasa pertengahan (41 - 60 tahun) yaitu 38 responden (95\%) dan 
39 responden $(97,5 \%)$. Jenis kelamin pada kelompok intervensi dan kelompok kontrol mayoritas adalah laki-laki yaitu 24 responden (60\%) dan 27 responden $(67,5 \%)$. Pendidikan sebagian besar SMA baik pada kelompok intervensi dan kelompok control yaitu 21 responden $(52,5 \%)$ dan 23 responden $(57,5 \%)$. Sebagian besar lama menderita $C H F$ pada kelompok intervensi dan kelompok kontrol $\geq 1$ tahun yaitu 22 responden $(55 \%)$ dan 29 responden $(72,5 \%)$. Semua karakterisitik responden memiliki nilai $p$ value lebih dari 0.05 sehingga semua karakteristik responden dikatakan homogen.

Gambaran hasil intervensi diet sodium dan pembatasan cairan terhadap keseimbangan cairan.

Tabel 9 Gambaran Keseimbangan cairan pre-test dan post-test pada kelompok intervensi dan kontrol $(\mathrm{n}=\mathbf{8 0})$

\begin{tabular}{|c|c|c|c|c|c|c|}
\hline & \multirow{2}{*}{$\begin{array}{c}\text { Keseimbangan } \\
\text { Cairan }\end{array}$} & \multicolumn{2}{|c|}{ Pre-test } & \multicolumn{2}{|c|}{ Post-test } & \multirow{2}{*}{$p$} \\
\hline & & $\mathrm{f}$ & $\%$ & $\mathrm{f}$ & $\%$ & \\
\hline \multirow{3}{*}{$\begin{array}{c}\text { Kelompok } \\
\text { kontrol }\end{array}$} & Tidak & 33 & 82,5 & 15 & 37,5 & \multirow{3}{*}{0,001} \\
\hline & Seimbang & & & & & \\
\hline & Seimbang & 7 & 17,5 & 25 & 62,5 & \\
\hline \multirow{3}{*}{$\begin{array}{l}\text { Kelompok } \\
\text { Intervensi }\end{array}$} & Tidak & 32 & 80 & 3 & 7,5 & \multirow{3}{*}{0,001} \\
\hline & Seimbang & & & & & \\
\hline & Seimbang & 8 & 20 & 37 & 92,5 & \\
\hline
\end{tabular}

Tabel 9 menunjukkan bahwa keseimbangan cairan baik pada kelompok intervensi maupun kontrol mengalami perubahan yang signifikan di tunjukan dengan nilai $\mathrm{p}=0,001$ yang berarti terdapat perbaikan yang signifikan pada post test.

Pengaruh penggunaan aplikasi diet sodium dan pembatasan cairan terhadap keseimbangan cairan pada pasien $\mathrm{CHF}$

Tabel 10 Gambaran Keseimbangan cairan pada kelompok intervensi dan kontrol (n=80)

\begin{tabular}{ccccccc}
\hline & \multirow{2}{*}{$\begin{array}{c}\text { Penilaian } \\
\text { mMRC }\end{array}$} & \multicolumn{2}{c}{ Pre-test } & \multicolumn{2}{c}{ Post-test } & \multirow{2}{*}{$p$} \\
\cline { 3 - 5 } & & $\mathrm{f}$ & $\%$ & $\mathrm{f}$ & $\%$ & \\
\hline \multirow{2}{*}{ Kelompok } & 1 & 0 & 0 & 0 & 0 & \\
kontrol & 2 & 0 & 0 & 22 & 55 & \multirow{2}{*}{0,001} \\
& 3 & 40 & 100 & 18 & 45 & \\
Kelompok & 4 & 0 & 0 & 0 & 0 & \\
Intervensi & 1 & 0 & 0 & 4 & 10 & \\
& 2 & 0 & 0 & 35 & 87,5 & \multirow{2}{*}{0,001} \\
& 3 & 40 & 100 & 1 & 2,5 & \\
\hline
\end{tabular}

Tabel 10 menunjukkan bahwa pada kedua kelompok, baik kelompok control maupun intervensi terjadi perbaikan pada keseimbangan cairan responden. Perbaikan cairan pada kelompok intervensi lebih signifikan dibandingkan kelompok control.

Perbaikan keseimbangan cairan ditunjukan oleh perubahan nilai mean yang mulai terlihat signifikan pada hari ke 6 . Keseimbangan cairan pada kelompok intervensi nilai mean pada pre test menurun dari 156,250 menjadi -6,250 pada post test. Pada kelompok kontrol nilai mean pada pre test menurun dari 156,875 menjadi 61,875 pada post test.

Tabel 11 Gambaran Keseimbangan cairan pada kelompok intervensi dan kontrol $(\mathbf{n}=\mathbf{8 0})$

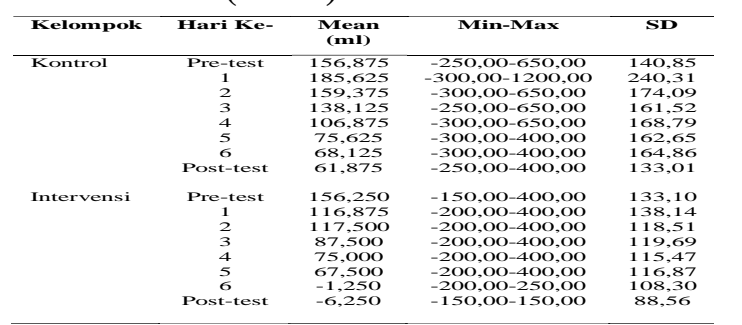

Tabel 11 menunjukkan bahwa frekwensi keseimbangan cairan yang seimbang pada kelompok intervensi diakhir masa penelitian lebih tinggi yaitu sebesar 37 responden $(92,5 \%)$ dibandingkan dengan kelompok kontrol yaitu sebesar 25 responden $(62,5 \%)$. Berdasarkan pengujian dengan chi square, pada kelompok intervensi terdapat hubungan antara pembatasan cairan dan diet sodium berbasis aplikasi dan keseimbangan cairan $(\mathrm{p}=0.001)$.

Gambaran pemberian intervensi diet sodium dan pembatasan cairan terhadap dyspnea.

Tabel 12 Gambaran Dyspnea pre-test dan post-test pada kelompok intervensi dan kontrol $(n=80)$ 


\begin{tabular}{|c|c|c|c|c|c|c|}
\hline \multirow{2}{*}{ Hari } & \multirow{2}{*}{$\begin{array}{c}\text { Keseimbangan } \\
\text { Cairan }\end{array}$} & \multicolumn{2}{|c|}{$\begin{array}{c}\text { Kelompok } \\
\text { Kontrol }\end{array}$} & \multicolumn{2}{|c|}{$\begin{array}{l}\text { Kelompok } \\
\text { Intervensi }\end{array}$} & \multirow{2}{*}{$\begin{array}{l}\text { Asymp } \\
\text {. Sig } \\
\text { Chi- } \\
\text { Square }\end{array}$} \\
\hline & & $f$ & $\%$ & $f$ & $\%$ & \\
\hline Pre test & $\begin{array}{l}\text { Tidak Seimbang } \\
\text { Seimbang }\end{array}$ & $\begin{array}{c}33 \\
7\end{array}$ & $\begin{array}{l}82,5 \\
17,5\end{array}$ & $\begin{array}{c}32 \\
8\end{array}$ & $\begin{array}{l}80 \\
20\end{array}$ & 0,770 \\
\hline $\mathrm{H}-1$ & $\begin{array}{l}\text { Tidak Seimbang } \\
\text { Seimbang }\end{array}$ & $\begin{array}{c}32 \\
8\end{array}$ & $\begin{array}{l}80 \\
20\end{array}$ & $\begin{array}{c}31 \\
9\end{array}$ & $\begin{array}{l}77,5 \\
22,5\end{array}$ & 0,786 \\
\hline $\mathbf{H}-2$ & $\begin{array}{l}\text { Tidak Seimbang } \\
\text { Seimbang }\end{array}$ & $\begin{array}{l}30 \\
10\end{array}$ & $\begin{array}{l}75 \\
25\end{array}$ & $\begin{array}{l}30 \\
10\end{array}$ & $\begin{array}{l}75 \\
25\end{array}$ & 1,000 \\
\hline $\mathbf{H}-3$ & $\begin{array}{l}\text { Tidak Seimbang } \\
\text { Seimbang }\end{array}$ & $\begin{array}{l}25 \\
15\end{array}$ & $\begin{array}{l}62,5 \\
37,5\end{array}$ & $\begin{array}{l}20 \\
20\end{array}$ & $\begin{array}{l}50 \\
50\end{array}$ & 0,260 \\
\hline $\mathbf{H}-4$ & $\begin{array}{l}\text { Tidak Seimbang } \\
\text { Seimbang }\end{array}$ & $\begin{array}{l}22 \\
18\end{array}$ & $\begin{array}{l}55 \\
45\end{array}$ & $\begin{array}{l}16 \\
24\end{array}$ & $\begin{array}{l}40 \\
60\end{array}$ & 0,178 \\
\hline $\mathbf{H}-5$ & $\begin{array}{l}\text { Tidak Seimbang } \\
\text { Seimbang }\end{array}$ & $\begin{array}{l}20 \\
20\end{array}$ & $\begin{array}{l}50 \\
50\end{array}$ & $\begin{array}{l}14 \\
26\end{array}$ & $\begin{array}{l}35 \\
65\end{array}$ & 0,172 \\
\hline$H-6$ & $\begin{array}{l}\text { Tidak Seimbang } \\
\text { Seimbang }\end{array}$ & $\begin{array}{l}20 \\
20\end{array}$ & $\begin{array}{l}50 \\
50\end{array}$ & $\begin{array}{c}8 \\
32\end{array}$ & $\begin{array}{l}20 \\
80\end{array}$ & 0,005 \\
\hline Post test & $\begin{array}{l}\text { Tidak Seimbang } \\
\text { Seimbang }\end{array}$ & $\begin{array}{l}15 \\
25\end{array}$ & $\begin{array}{l}37,5 \\
62,5\end{array}$ & $\begin{array}{c}22 \\
3 \\
37\end{array}$ & $\begin{array}{l}7,5 \\
92,5\end{array}$ & 0,001 \\
\hline
\end{tabular}

Tabel 12 menunjukkan bahwa peraikan gejala Dyspnea baik pada kelompok intervensi maupun kontrol mengalami perbaikan yang signifikan di tunjukan dengan nila1 $\mathrm{p}=0,001$ yang berarti terdapat perbaikan yang signifikan pada post test.

Pengaruh penggunaan aplikasi diet sodium dan pembatasan cairan terhadap dyspnea pada pasien $\mathrm{CHF}$

Gambaran dyspnea yang dialami responden baik pada kelompok intervensi dan kelompok kontrol. Klasifikasi gejala Dyspnea ditentukan berdasarkan nilai $m M R C$.

Tabel 13 Gambaran Dyspnea pada kelompok intervensi dan kontrol $(\mathbf{n}=\mathbf{8 0})$

\begin{tabular}{|c|c|c|c|c|c|c|}
\hline & \multirow{2}{*}{$\begin{array}{l}\text { Dyspnea } \\
\text { (mMRC) }\end{array}$} & \multicolumn{2}{|c|}{ Kontrol } & \multicolumn{2}{|c|}{ Intervensi } & \multirow[t]{2}{*}{$P$} \\
\hline & & $\mathrm{f}$ & $\%$ & $\mathrm{f}$ & $\%$ & \\
\hline \multirow{4}{*}{ Pre test } & 1 & 0 & 0 & 0 & 0 & \multirow{4}{*}{1,000} \\
\hline & 2 & 0 & 0 & 0 & 0 & \\
\hline & 3 & 40 & 100 & 40 & 100 & \\
\hline & 4 & 0 & 0 & 0 & 0 & \\
\hline \multirow{4}{*}{$\mathrm{H}-1$} & 1 & 0 & 0 & 0 & 0 & \multirow{4}{*}{0,590} \\
\hline & 2 & 8 & 20 & 10 & 25 & \\
\hline & 3 & 32 & 80 & 30 & 75 & \\
\hline & 4 & 0 & 0 & 0 & 0 & \\
\hline \multirow{4}{*}{$\mathrm{H}-2$} & 1 & 0 & 0 & 0 & 0 & \multirow{4}{*}{0,242} \\
\hline & 2 & 12 & 30 & 17 & 42,5 & \\
\hline & 3 & 28 & 70 & 23 & 57,5 & \\
\hline & 4 & 0 & 0 & 0 & 0 & \\
\hline \multirow{4}{*}{$\mathrm{H}-3$} & 1 & 0 & 0 & 0 & 0 & \multirow{4}{*}{0,183} \\
\hline & 2 & 16 & 40 & 22 & 55 & \\
\hline & 3 & 24 & 60 & 18 & 45 & \\
\hline & 4 & 0 & 0 & 0 & 0 & \\
\hline \multirow{4}{*}{$\mathrm{H}-4$} & 1 & 0 & 0 & 0 & 0 & \multirow{4}{*}{0,122} \\
\hline & 2 & 18 & 45 & 22 & 62,5 & \\
\hline & 3 & 22 & 55 & 18 & 37,5 & \\
\hline & 4 & 0 & 0 & 0 & 0 & \\
\hline \multirow{4}{*}{$\mathrm{H}-5$} & 1 & 0 & 0 & 0 & 0 & \multirow{4}{*}{0,110} \\
\hline & 2 & 20 & 50 & 27 & 67,5 & \\
\hline & 3 & 20 & 50 & 13 & 32,5 & \\
\hline & 4 & 0 & 0 & 0 & 0 & \\
\hline \multirow{4}{*}{$H-6$} & 1 & 0 & 0 & 0 & 0 & \multirow{4}{*}{0,024} \\
\hline & 2 & 20 & 50 & 30 & 75 & \\
\hline & 3 & 20 & 50 & 10 & 25 & \\
\hline & 4 & 0 & 0 & 0 & 0 & \\
\hline \multirow{2}{*}{ Post test } & 1 & 0 & 0 & 4 & 10 & \multirow{2}{*}{0,001} \\
\hline & 2 & 22 & 55 & 35 & 87,5 & \\
\hline
\end{tabular}

\begin{tabular}{cccccc}
\hline $\begin{array}{c}\text { Dyspnea } \\
\text { (mMRC) }\end{array}$ & \multicolumn{2}{c}{ Kontrol } & \multicolumn{2}{c}{ Intervensi } & \\
\cline { 2 - 5 } & $\mathrm{f}$ & $\%$ & $\mathrm{f}$ & $\%$ \\
\hline 3 & 18 & 45 & 1 & 2,5 \\
& 0 & 0 & 0 & 0 & \\
\hline
\end{tabular}

Tabel 13 menunjukkan nilai $p<0.05$ dimulai pada hari ke 6. Nilai ini menunjukkan adanya pengaruh signifikan penurunan gejala dyspnea pada kelompok intervensi yang mendapatkan pembatasan cairan dan diet sodium berbasis aplikasi pada pasien dengan gagal jantung kongestif NYHA II.

\section{PEMBAHASAN}

\section{Karakteristik Responden}

Karakteristik responden yang berkaitan dengan penelitian ini meliputi: usia, jenis kelamin, pendidikan, lama menderita $\mathrm{CHF}$ yang merupakan variabel confounding karena memiliki hubungan dan mempengaruhi penelitian. Pada kelompok kontrol dan kelompok intervensi usia sebagian besar berada di kategori dewasa pertengahan yaitu 41-60 tahun.

Penelitian oleh Kumalasari di RSUP dr Kariadi menunjukan bahwa pasien $C H F$ terbanyak pada usia 41-60 tahun sebanyak $40,9 \% .^{73}$ Penelitian ini sama dengan penelitian Caroline di Makasar yang menyebutkan bahwa usia tertinggi pada $C H F$ berada pada kelompok usia 41-50 tahun sebesar 37,5\% dan 51-60 tahun sebesar 25\% serta 61-70 tahun sebesar $30 \% .^{74}$ Kondisi lanjut usia akan menyebabkan beberapa perubahan anatomi dan fisiologi yang dapat berpengaruh pada seluruh anatomi tubuh, fungsi sel dan jaringan atau organ. Perubahan tersebut juga terjadi pada sistem respirasi dan kardiovaskuler. Faktor pendukung seperti penyakit, perubahan pada fungsi sistem respirasi dan kardiovaskuler akan mempengaruhi fungsi keseluruhan pada lansia. $^{72}$

Penelitian lain yaitu penelitian oleh Widagdo yang menunjukkan bahwa distribusi penyakit $C H F$ meningkat pada usia 40 tahun ke atas. Hasil penelitian menunjukkan responden berusia 41-60 tahun sebanyak $46,6 \%$ dan responden usia >60 tahun sebanyak $36,7 \% .^{71}$ Usia yang semakin bertambah akan meningkatkan resiko terkena 
serangan jantung. ${ }^{75}$ Prevalensi penyakit $C H F$ meningkat seiring dengan bertambahnya umur dan tertinggi pada umur 65-74 tahun $(0,5 \%){ }^{76}$ Hal ini disebabkan karena proses penuaan akan menyebabkan aterosklerosis sehingga aliran darah dan nutrisi jaringan terhambat. Aterosklerosis yang muncul akan mengganggu perfusi jaringan sehingga meningkatkan tekanan vaskuler perifer. ${ }^{77}$

Karakteristik jenis kelamin pada responden menunjukkan lebih banyak responden berjenis kelamin laki-laki baik pada kelompok kontrol dan kelompok intervensi. Jenis kelamin pada kelompok intervensi dan kelompok kontrol mayoritas adalah laki-laki yaitu 24 responden $(60 \%)$ dan 27 responden $(67,5 \%)$. Hasil penelitian ini sejalan dengan penelitian Hamzah menunjukkan bahwa penyakit $C H F$ lebih banyak terjadi pada laki-laki dengan persentase $60 \% .^{78}$ Penelitian Maulidta juga menunjukkan bahwa laki-laki lebih banyak menderita $C H F$ dengan jumlah 63,30\%. ${ }^{79}$

Hasil penelitian ini juga didukung oleh penelitian Mehta dan Cowie pada pasien gagal jantung yang menunjukkan jenis kelamin responden laki-laki sebesar $55 \%$ sedangkan laki-laki $45 \% .{ }^{80}$ Penelitian yang dilakukan oleh Imelda pada tahun 2016 mendapatkan hasil yang sama, dimana jumlah responden yang mengalami gagal jantng kongestif dengan jenis kelamin laki-laki memiliki persentase lebih besar dibandingkan perempuan yaitu sebesar 57,6\%. ${ }^{22}$ Jenis kelamin merupakan suatu hal yang menjadi identitas bagi responden yang dapat membedakan antara responden satu dengan yang lainnya. Laki-laki menjadi responden dengan jumlah paling banyak dalam penelitian. Laki-laki pada umumnya memiliki kebiasaan hidup yang kurang baik di antaranya merokok dan memiliki aktivitas yang lebih tinggi. Hal ini menyebabkan Lakilaki lebih banyak menderita penyakit jantung. ${ }^{59}$

Karakteristik pendidikan pada responden menunjukkan lebih banyak responden dengan tingkat pendidikan SMA baik pada kelompok kontrol dan kelompok intervensi. Responden dengan pendidikan SMA berjumlah 44 orang.
Hasil penelitian ini sejalan dengan penelitian Hamzah menunjukkan bahwa penyakit $\mathrm{CHF}$ lebih banyak terjadi pada responden dengan tingkat pendidikan SMA dengan persentase $66,7 \% .{ }^{78}$ Penelitian Imelda pada tahun 2016 juga menyatakan bahwa responden dengan tingkat pendidikan SMA memiliki persentase lebih besar yaitu sebesar 54,5\%. ${ }^{61}$

Latar belakang pendidikan erat kaitanya dengan tingkat pengetahuan seseorang. Tingkat pendidikan sangat menentukan kemampuan pasien untuk memahami tentang kondisi kesehatannya. Individu yang memiliki tingkat pendidikan rendah akan mengalami kesulitan untuk mengenal masalah kesehatan serta memahami panduan penanganan penyakit dibandingkan dengan individu yang memiliki tingkat pendidikan lebih tinggi. Kemampuan pasien yang baik tersebut akan meningkatkan pengenalan pasien terhadap faktor yang mempengaruhi kesehatannya dan efek jangka panjang terhadap kesehatannya tersebut.

Penelitian oleh Anisa pada tahun 2017 menunjukan hasil responden yang mengalami gagal jantung dengan tingkat pendidikan SMA memiliki persentase paling besar dibandikan dengan tingkat pendidikan lainya, yaitu sebesar 30\%. ${ }^{62}$ Menurut Natoatmojo perubahan atau tindakan pemeliharaan dan peningkatan kesehatan yang dihasilkan oleh pendidikan kesehatan ini didasarkan pada pengetahuan dan kesadaran melalui proses pembelajaran. Moons, mengungkapkan pendidikan adalah faktor yang dapat mempengaruhi kualitas hidup. Semakin tinggi pendidikan seseorang juga diharapkan memiliki kualitas hidup yang semakin baik. Pasien yang memiliki tingkat pendidikan yang tinggi memiliki hubungan dengan kemampuan self care behavior dan kepatuhan terhadap diet dan pengobatan. Tingkat pendidikan sangat menentukan kemampuan pasien untuk memahami tentang kondisi kesehatannya serta mampu menerima intervensi yang diberikan dalam penelitian. ${ }^{64}$

Karakteristik lama menderita gagal jantung kongestif pada responden menunjukkan lebih banyak responden dengan lama terdiagnosa mengalami gagal jantung 
kongestif lebih dari 1 tahun baik pada kelompok kontrol dan kelompok intervensi. Responden dengan lama terdiagnosa gagal jantung $>1$ tahun memiliki persentase sebesar 63,7\%. Penelitian ini sejalan dengan penelitian dilakukan oleh Pudiarifanti, Pramantara \& Ikawati (2015) sebagian besar yaitu $73 \%$ responden stadium 2 dan $52 \%$ responden menderita gagal jantung $>1$ tahun. Semakin lama seseorang menderita gagal jantung dengan stadium 2 maka fungsi jantung akan mengalami penurunan, sehingga terjadi penurunan cardiac output. Penurunan cardiac out-put akan membuat jantung terkompensasi untuk bekerja lebih kuat dengan harapan mampu memenuhi kebutuhan tubuhnya, tetapi dengan kronisnya kondisi jantung semakin gagal dalam memompa. ${ }^{67}$

Data American Heart Association (2012) menyatakan pasien yang mengalami hospitalisasi akibat $C H F$ sebanyak 1.094.000 pasien dengan kejadian rehospitalisasi hampir sekitar $50 \%$ dari total pasien $C H F$ yang pernah menjalani hospitalisasi sebelumnya. ${ }^{66}$ Pasien $C H F$ yang sering kembali untuk dirawat inap ulang di rumah sakit karena adanya kekambuhan pada episode $C H F$. Kebanyakan kekambuhan $\mathrm{CHF}$ terjadi karena pasien tidak memenuhi terapi yang dianjurkan misalnya tidak mampu melaksanakan terapi pengobatan dengan tepat, melanggar pembatasan diet, tidak mematuhi tindak lanjut medis, melakukan aktivitas fisik yang berlebihan dan tidak dapat mengenali gejala kekambuhan. ${ }^{64}$

\section{Gambaran Hasil Intervensi Diet Sodium Dan Pembatasan Cairan}

Gambaran keseimbangan cairan baik pada kelompok kontrol maupun intervensi mengalami perbaikan pada akhir penelitian (post-test). Kelompok kontrol mengalami peningkatan frekwensi keseimbangan cairan yaitu dari $7(17,5 \%)$ orang menjadi 25 $(62,5 \%)$ orang pada akhir masa penelitian (post-test) sedangkan kelompok intervensi mengalami peningkatan frekwensi balance cairan yaitu dari $8(20 \%)$ orang menjadi 37 $(92,5 \%)$ orang pada akhir masa penelitian (post-test). Sejalan dengan penelitian Henriette Philipson, perbaikan juga terjadi pada keseimbangan volume cairan (urinary volume $24 \mathrm{~h}$ ), dengan hasil mean yaitu 1,56 pada kelompok kontrol sedangkan pada kelompk intervensi didapatkan nilai mean 1,54 dengan nilai signifikansi $p=0,04$.

Keseimbangan cairan terlihat baik pada kelompok intervensi dan kelompok kontrol, hal ini disebabkan karena kedua kelompok ini mendapatkan terapi diuretik dan pengobatan yang didapatkan dari rumah sakit, dimana diuretik berperan dalam menurunkan volume plasma dan selanjutnya menurunkan aliran balik vena (venous return) menuju jantung (preload), hal ini akan menurunkan beban kerja jantung dan kebutuhan oksigen. Diuretik juga menurunkan afterload dengan mengurangi volume plasma yang selanjutnya menurunkan tekanan darah. Pemberian diuretik juga mengurangi gejala retensi cairan yang diantaranya meningkatnya tekanan vena jugularis atau edema ataupun keduanya. Diuretik menghilangkan retensi natrium pada CHF dengan menghambat reabsorbsi natrium atau klorida pada sisi spesifik di tubulus ginjal. Bumetamid, furosemid, dan torsemid bekerja pada tubulus distal ginjal. ${ }^{68}$

Penelitian lain yang mendukung ditunjukan dalam penelitian d`Almeida (2018) dengan intervensi pembatasan cairan dan diet sodium dengan 30 responden pasien dengan gagal jantung NYHA II. Penilaian yang dilakukan dalam penelitian ini yaitu dengan menghitung intake dan output selama 24 jam dalam satu hari. Kedua kelompok baik intervesi maupun kontrol mengalami perbaikan, namun pada kelompok intervensi didapatkan hasil 582.7 (496.9-662.4) dengan nilai $\mathrm{p}=0.001$. yang artinya kelompok intervensi memiliki kecenderungan lebih baik dalam perbaikan keseimbangan cairan dibandingkan dengan kelompok kontrol. ${ }^{42}$ Tujuan manajemen nutrisi pada pasien gagal jantung adalah untuk mengurangi natrium dan retensi cairan. Pembatasan natrium ditujukan untuk mencegah, mengatur atau mengurangi edema.

Pengaruh Pemberian Intervensi Diet Sodium dan Pembatasan Cairan Berbasis 
Jurnal Ilmu Sosial dan Pendidikan

http://ejournal.mandalanursa.org/index.php/JISIP/index

Terakreditasi Peringkat 5 (No. SK: 85/M/KPT/2020)

\section{Aplikasi terhadap Perbaikan Keseimbangan Cairan.}

Keseimbangan cairan baik pada kelompok intervensi maupun kontrol mengalami perbaikan dengan nilai mean pada kelompok kontrol pada pre-test yaitu $157 \mathrm{ml}$ menjadi 62 ml pada post-test, sedangkan pada kelompok intervensi nilai mean pada pre-test $156 \mathrm{ml}$ menjadi $-6 \mathrm{ml}$ pada post-test. Hasil ini sama dengan hasil penelitian Salvatore Paterna (2014) dengan intervensi pembatasan cairan dan diet sodium dengan 232 responden pasien dengan gagal jantung NYHA II. Penilaian yang dilakukan dalam penelitian ini yaitu dengan menghitung intake dan output total selama 24 jam dalam satu hari. Kedua kelompok baik intervesi maupun kontrol mengalami perbaikan, namun pada kelompok intervensi menunjukan kecenderungan lebih baik dalam perbaikan keseimbangan cairan dibandingkan dengan kelompok kontrol. ${ }^{84}$

Cairan dalam tubuh manusia normalnya adalah seimbang antara asupan (input) dan haluaran (output). Jumlah asupan cairan harus sama dengan jumlah cairan yang dikeluarkan dari tubuh. Perubahan sedikit pada keseimbangan cairan dan elektrolit tidak akan memberikan dampak bagi tubuh. Semakin kecil nilai pada hasil perhitungan kesimbangan cairan makan keseimbangan cairan dapat dikatakan semakin baik. ${ }^{73}$

Kelompok intervensi mendapat intervensi berupa aplikasi untuk menjaga asupan cairan dan diet sodium didapatkan hasil peningkatan keseimbangan cairan lebih tinggi dibandingkan dengan kelompok kontrol yang hanya mendapatkan intervensi standar rumah sakit. $^{71}$ Pemantauan keseimbangan cairan dilakukan dengan menggunakan aplikasi pembatasan cairan dan diet sodium. Melalui aplikasi pembatasan cairan dan diet sodium responden lebih mudah dalam melakukan monitoring cairan mulai dari perhitungan kebutuhan cairan perhari, pencatatan dan penjumlah jumlah cairan yang telah dikonsumsi. Aplikasi pembatasan cairan dan diet sodium juga memiliki sistem reminder dimana aplikasi akan membunyikan alarm jika batas pemasukan cairan perhari sudah dipenuhi. Aplikasi pembatasan cairan dan diet
Vol. 5. No. 1 Januari 2021

p-ISSN: 2598-9944 e- ISSN: 2656-6753

sodium juga memiliki menu yang memiliki konten pendidikan kesehatan, dimana dengan menu ini pasien lebih mudah mengetahui halhal yang terkait pembatasan cairan serta tidak perlu kesulitan membawa kertas untuk dibaca. ${ }^{73}$

Penggunaan aplikasi pada kelompok intervensi menunjukan hasil yang lebih signifikasn dalam meningkatkan keseimbangan cairan pada pasien $C H F$. Perbaikan keseimbangan cairan pada responden mulai ditunjukan secara signifikan pada hari ke 6 , hal ini menunjukan bahwa penggunaan aplikasi sebagai basis dalam menerapkan intervensi pembatasan cairan setidaknya digunakan selama 6 hari untuk dapat menunjukan hasil yang baik. Artikel review menyebutkan bahwa mobile teknologi dapat digunakan untuk memberikan eduksi kepada pasien. ${ }^{81}$ Hal ini mendukung aplikasi yang dikembangkan oleh peneliti yaitu memiliki menu yang memberikan edukasi kesehatan. Mobile phone memiliki peran yang sangat penting dalam melakukan edukasi. ${ }^{82}$ Mobile phone dapat juga digunakan untuk melakukan monitoring. ${ }^{81-83}$ Hasil yang menunjukan perbaikan status keseimbangan cairan pada responden dipengaruhi oleh penggunaan aplikasi yang mempermudah penerapan pembatasan cairan dan diet sodium, hal ini dapat terjadi karena adanya kemudahan penggunaan (ease of use) dan kemanfaatan (usefulness). Usefulness merupakan tingkat kepecayaan seseorang dimana dengan menggunakan bagian dari sistem akan membantunya dalam melakukan tugas kesehariannya, dimana pada pasien CHF teknologi aplikasi diet sodium dan pembatasan cairan akan membantu pasien dengan gagal jantung dalam menjaga keseimbangan cairan dengan cara yang mudah dan memiliki manfaat besar dala, penggunaannya. ${ }^{60}$

Keseimbangan ini dipertahankan oleh asupan, distribusi, dan haluaran air dan elektrolit, serta pengaturan komponenkomponen tersebut oleh sistem renal dan paru. Banyak faktor yang menyebabkan ketidakseimbangan salah satu yang memiliki peran penting yaitu kelebihan Natrium yang 
meningkatkan retensi air sehingga meningkatkan volume plasma dan menyebabkan peningkatan tekanan darah arteri. Pada kondisi gagal jantung, kapasitas adaptif tubuh tidak lagi mampu mempertahankan keseimbangan cairan dan elektrolit secara normal sehingga membutuhkan pembatasan asupan untuk mengurangi beban kerja organ tubuh terutama jantung dalam memompkan darah. Pembatasan cairan juga bertujuan mengurangi terjadinya edema pada jaringan tubuh terutama pada bagian paru sehingga menurunkan gejala sesak nafas pada pasien gagal jantung. ${ }^{66}$

Peningkatan volume cairan total dalam tubuh yang juga dipengaruhi oleh asupan cairan yang berlebih, dipicu oleh keluarnya vasopresin menyebabkan peningkatan aquoporin waterchanel pada collecting duct yang menyebabkan retensi cairan dan berkontribusi dalam menyebabkan terjadinya hipervolemia. Membatasi konsumsi cairan dengan program yang tepat dapat menurunkan kejadian hipovolemia dalam tubuh. Restriksi cairan dilakukan seiring dengan restriksi natrium pada keadaan retensi cairan. Berbagai macam rekomendasi jumlah cairan yang boleh dikonsumsi pada pasien gagal jantung yaitu berkisar antara $800 \mathrm{~mL}-1500 \mathrm{~mL}{ }^{69}$

Pasien dengan kondisi penyakit kronik memerlukan suatu sistem yang mendukung dalam pemeliharaan kesehatan sehingga pasien mampu melakukan self-care. Teknologi kesehatan berbasis sistem kesehatan yang berkesinambungan dapat mendukung pasien dalam melakukan selfcare terhadap kesehatan mereka. ${ }^{85}$ Hasil penelitian ini juga sesuai dengan teori keperawatan Orem yang menitikberatkan sistem pemeliharaan kesehatan secara mandiri dalam hal ini bagi pasien gagal jantung kongestif. Pembatasan konsumsi cairan yang dilakukan oleh pasien dengan gagal jantung kongestif NYHA II dapat dilakukan secara mandiri, hal ini dimungkinkan sebab pasien dengan NYHA II masih mampu melakukan kegiatan secara mandiri. Reponden penelitian dapat lebih maksimal melakukan self-care pembatasan cairan dengan bantuan dari teknologi kesehatan yaitu pembatasan cairan dan diet sodium. Penelitian menyebutkan bahwa penggunaan aplikasi kesehatan dapat membantu seseorang dalam meningkatkan perubahan kebiasaan kesehatannya dan membantu pada kompleksnya pengobatan yang dijalani pasien. ${ }^{82}$

Penelitian-penelitian sebelumnya telah menunjukkan signifikansi yang cukup baik, namun effect size pada penelitian-penelitian sebelumnya masih dalam kategori lemah. Hal ini dibuktikan dari penelitian-penelitian sebelumnya yang mempunyai effect size yaitu sebesar 0.2 , lebih rendah dari penelitian sekarang dengan nilai effect size 0.5 . Hal ini membuktikan bahwa intervensi diet sodium dan pembatassan cairan berbasis aplikasi android lebih efektif dalam memperbaiki keseimbangan cairan pada pasien $\mathrm{CHF}$ dibandingkan dengan intervensi standar rumah sakit dan intervensi yang dilakukan pada penelitian-penelitian sebelumnya.

\section{Gambaran hasil Intervensi Diet Sodium Dan Pembatasan Cairan}

Gambaran kejadian sesak mengalami penurunan baik pada kelompok kontrol maupun intervensi. Pada kelompok kontrol terjadi penurunan gejala dyspnea skala 3 dari 40 orang menjadi 18 orang dan 22 orang berada pada skala 2, sedangkan kelompok intervensi terjadi penurunan kejadian dyspnea dari skala 3 dari 40 orang menjadi 1 orang, 35 orang berada pada skala 2 , dan 4 orang berada pada skala 1 . Gejala dyspnea baik pada kelompok intervensi maupun kontrol mengalami perubahan yang ditujukan dengan nilai $\mathrm{p}=0,001$ yang berarti terdapat perbaikan gejala dyspnea yang signifikan pada post-test dibandingkan saat pre-test.

Sejalan penelitian Henriette Philipson, perbaikan juga terjadi pada keseimbangan volume cairan (urinary volume $24 \mathrm{~h}$ ), dengan hasil mean yaitu 1,56 pada kelompok kontrol sedangkan pada kelompk intervensi didapatkan nilai mean 1,54 dengan nilai signifikansi $p=0,04$. Gejala sesak napas yang dialami oleh pasien dengan gagal jantung kongestif $(\mathrm{CHF})$ fokus pada bagaimana berkurangnya curah jantung pada saat aktifitas menyebabkan gangguan suplai darah 
otot skelet, sehingga menyebabkan kelelahan, dan pengisian ventrikel kiri yang meningkat. Tekanan untuk mempertahankan hasil ejeksi oleh jantung dalam mengurangi difusi pulmonal karena edema interstisial, sehingga menyebabkan sesak napas. Terjadinya edema pada pulmonal diperparah dengan kelebihan kadar sodium dalam tubuh, sodium atau garam dalam tubuh menyebabkan terjadinya restriksi atau penahanan terhadap cairan. Jumlah atau volume cairan yang berlebih menyebabkan kerja jantung meningkat serta menyebabkan meningkatnya skala sesak nafas. Diet sodium serta pembatasan cairan dilakukan untuk mengurangi gejala-gejala kerja jantung yang semakin berat serta derajat edema, baik pada jaringan pulmonal maupun seluruh tubuh.

Kompliansi paru yang meningkat dapat terjadi karena penurunan kongesti pada paruparu yang selanjutnya dapat menyebabkan jumlah udara yang masuk kedalam paru juga meningkat, sehingga gejala sesak nafas dapat menurun. Pembatasan konsumsi cairan dan diet sodium dapat menurunkan retensi cairan sehingga menurunkan edema pada paru-paru dan meminimalkan penggunaan otot bantu pernapasan. Dengan melakukan diet sodium dan pembatasan cairan, maka fungsi pernafasan akan membaik. ${ }^{55}$

\section{Pengaruh Pemberian Intervensi Diet} Sodium Dan Pembatasan Cairan Berbasis Aplikasi Terhadap Penurunan Dyspnea.

Hasil analisis uji beda secara keseluruhan selama 7 hari menunjukkan nilai $\mathrm{p}$ value $p=0.001$ yang artinya nilainya $<0.05$. Nilai ini menunjukkan adanya pengaruh signifikan kejadian dyspnea pada kelompok intervensi yang mendapatkan pembatasan cairan dan diet sodium berbasis aplikasi pada pasien dengan gagal jantung kongestif NYHA II dibandingkan dengan kelompok kontrol. Penilaian skala sesak nafas dengan nilai $m M R C 0$ sampai 4 dan cut of points $m M R C$ adalah 2. Penderita sesak dengan nilai $m M R C$ lebih dari dua mempunyai sesak napas yang lebih berat. Melihat hasil dari dari penelitian yang telah dilakukan, responden yang mengalami sesak skala 3 dari 40 orang turun menjadi 1 orang, hal ini menunjukan bahwa mayoritas responden pada kelompok intervensi mengalami perbaikan skala sesak dari berat menjadi ringan dengan bantuan aplikasi diet sodium dan pembatasan cairan. ${ }^{86}$

Penelitian oleh Witowo tahun 2018 dengan melakukan penilaian terhadap status dyspnea pada pasien $C H F$ menunjukan hasil yang belum signifikan, intervensi yang dilakukan yaitu dengan hypno-breathing exercise. ${ }^{74}$ Dengan demikian dapat dikatakan intervensi pembatasan diet sodium dan pembatasan cairan dapat dijadikan pilihan untuk intervensi non-farmakologis bagi pasien $\mathrm{CHF}$ yang menunjukan gejala dyspnea.

Penelitian oleh Henriette Philipson 2012 dengan 90 responden pasien dengan gagal jantung NYHA II. Penilaian yang dilakukan dalam penelitian ini yaitu dengan menilai kadar sodium serum dan perbaikan edema pada responden baik kelompok kontrol maupun intervensi. Dari hasil penelitian menunjukan kedua kelompok baik intervesi maupun kontrol mengalami perbaikan, tidak ada perbedaan yang berarti jika dilihat dari penurunan kadar sodium serum, namun perbaikan kadar sodium dalam tubuh dilihat dari perbaikan edema, pada kelompok intervensi terjadi perbaikan yang lebih signifikan dibandingkan kelompok kontrol. Kadar sodium dalam tubuh yang mempengaruhi restriksi cairan lebih rendah pada kelompok intervensi, sehingga dapat mengurangi skala edema pada pasien, ternasuk edema yang terjadi pada jaringa paru-paru sehingga dapat menurunkan gejala sesak nafas. $^{74}$

Pada kelompok intervensi pemantauan gejala sesak nafas atau dyspnea dilakukan dengan menggunakan aplikasi pembatasan cairan dan diet sodium. Melalui aplikasi pembatasan cairan dan diet sodium responden lebih mudah dalam melakukan pencatatan skala dyspnea yang dirasakan. Aplikasi pembatasan cairan dan diet sodium memiliki menu khusus yang digunakan untuk melakukan input data gejala dyspnea yang dirasakan, setiap kali responden merasakan gejala sesak makan pasien harus melakukan input gejala sesuai dengan skala yang 
dirasakan. Indikator gejala sesak mengacu pada penilaian berdasarkan nilai $m M R C$ yang terdiri atas 5 skala. $^{71}$

Instrumen pengukuran (dyspnea) yang digunakan merupakan instrument penilaian dyspnea pada pasien dengan penyakit gangguan pernafasan yang diakibatkan oleh peyakit paru obstruktif, hal ini karena belum ada instrument khusus yang dapat digunakan untuk mengukur dyspnea yang secara khusus terjadi pada pasien dengan gagal jantung kongestif. Pengembangan dan penggunaan instrument yang khusus mengukur gejala dyspnea pada pasien gagal jantung kongestif sangat dibutuhkan agar meningkatkan sensitivity pengukuran dyspnea pada pasien gagal jantung kongestif.

Penggunaan aplikasi pada kelompok intervensi menunjukan hasil yang lebih signifikan dalam perbaikan gejala dyspnea pada pasien $C H F$. Menurunnya gejala dyspnea pada responden terjadi sejalan dengan perbaikan keseimbangan cairan. Perbaikan keseimbangan cairan pada responden mulai ditunjukan secara signifikan pada hari ke 6 , begitupula pada perbaikan gejala dyspnea, hal ini menunjukan bahwa penggunaan aplikasi sebagai basis dalam menerapkan intervensi pembatasan cairan dan diet sodium dapat secara signifikan pula memperbaiki gejala dyspnea pada pasien dengan $C H F$. Penggunaan aplikasi diet sodium dan pembatasan cairan yang digunakan pada penelitian ini menunjukan hasil yang baik, hal ini ditunjukan dengnan perbaikan keseimbangan cairan dan penurunan gejala dyspnea, akan tetapi pengembangan secara berkelanjutan masih perlu dilakukan pada aplikasi tersebut. Pengembangan pada aplikasi dibutuhkan untuk meningkatkan confidency agar dapat digunakan secara luas bagi pasien dengan gagal jantung kongestif.

Kelompok intervensi mendapat intervensi berupa aplikasi untuk menjaga asupan cairan dan diet sodium didapatkan hasil peningkatan keseimbangan cairan lebih tinggi dibandingkan dengan kelompok kontrol yang hanya mendapatkan intervensi standar rumah sakit. ${ }^{71}$ Pemantauan keseimbangan cairan dilakukan dengan menggunakan aplikasi pembatasan cairan dan diet sodium. Melalui aplikasi pembatasan cairan dan diet sodium responden lebih mudah dalam melakukan monitoring cairan mulai dari perhitungan kebutuhan cairan perhari, pencatatan dan penjumlah jumlah cairan yang telah dikonsumsi. Aplikasi pembatasan cairan dan diet sodium juga memiliki sistem reminder dimana aplikasi akan membunyikan alarm jika batas pemasukan cairan perhari sudah dipenuhi. Aplikasi aplikasi pembatasan cairan dan diet sodium juga memiliki menu yang memiliki konten pendidikan kesehatan, dimana dengan menu ini pasien lebih mudah mengetahui hal-hal yang terkait pembatasan cairan serta tidak perlu kesulitan melakukan pencatatan secara konvensional. ${ }^{73}$

Artikel review menyebutkan bahwa mobile teknologi dapat digunakan untuk memberikan eduksi kepada pasien. ${ }^{81}$ Hal ini mendukung aplikasi yang dikembangkan oleh peneliti yaitu memiliki menu yang memberikan edukasi kesehatan. Mobile phone memiliki peran yang sangat penting dalam melakukan edukasi. ${ }^{82}$ Mobile phone dapat juga digunakan untuk melakukan monitoring. ${ }^{81-83}$ Hasil yang menunjukan perbaikan gejala dyspnea pada responden dipengaruhi oleh penggunaan aplikasi yang mempermudah penerapan pembatasan cairan dan diet sodium, hal ini dapat terjadi karena adanya kemudahan penggunaan (ease of use) dan kemanfaatan (usefulness). Usefulness merupakan tingkat kepecayaan seseorang dimana dengan menggunakan bagian dari sistem akan membantunya dalam melakukan tugas kesehariannya, dimana pada pasien CHF teknologi aplikasi diet sodium dan pembatasan cairan akan membantu pasien dalam memeperbaiki gejala dyspnea dengan cara yang mudah dan memiliki manfaat besar dala, penggunaannya. ${ }^{60}$

Dyspnea disebabkan oleh peningkatan kerja pernapasan sebagai akibat terjadinya kongesti vaskular paru yang menurunkan fungsi paru-paru. Kongesti yang terjadi mulai dari kongesti vena sampai edema interstisial paru dan akhirnya menjadi edema alveolar. Gejala dyspnea diperberat dengan 
penumpumpukan cairan yang diakibatkan oleh restriksi sodium dalam tubuh. Sodium adalah bentuk natrium dalam tubuh, natrium merupakan kation utama dalam cairan ekstraselular. $30-40 \%$ natrium ada di dalam kerangka tubuh. Di dalam tubuh, natrium terdapat di dalam sel (intra selular) dan terutama terdapat dalam cairan di luar sel (cairan ekstra selular). Perubahan keseimbangan cairan serta kandungan sodium dalam tubuh memiliki peran penting dalam munculnya gejala gagal jantung kongestif, terutama sesak nafas. ${ }^{73}$

Penurunan stroke volume akan meningkatkan end sistolic volume sehingga volume dalam ventrikel kiri meningkat, ini menjadi faktor berikutnya munculnya gejala sesak nafas pada pasien gagal jantung. Peningkatan volume mengakibatkan meregangnya dinding ventrikel kiri sehingga otot jantung akan berkontraksi dengan lebih kuat untuk meningkatkan curah jantung untuk memenuhi kebutuhan memompa semua darah sehingga end diastolic volume meningkat dan tekanan ventrikel kiri juga meningkat. Tekanan ini akan ditransmisikan ke atrium kiri, vena pulmonal dan kapiler pulmonal. Hal ini akan menyebabkan edema paru metabolik tubuh. Terjadinya edema paru menyebabkan timbulnya gejala khas pada kondisi gagal jantung kongestif yaitu gejala sesak nafas atau dyspnea. Dyspnea adalah manifestasi gagal jantung yang paling sering ditemukan. ${ }^{75}$

Penggunaan sekala $m M R C$ selama ini masih dilakukan secara manual, dengan dukungan teknologi kesehatan berbasis aplikasi dapat mendukung pasien dalam melakukan self-care. Pada penelitian ini, responden dapat melakukan pencatatan gejala sesak kapan saja, serta dapat dengan mudah melihat indikator skala sesak nafas yang telah dimasukan dalam aplikasi pembatasan cairan dan diet sodium. Intervensi yang diberikan diharapkan dapat mempermudah pasien dalam menerapkan self-care dengan baik terhadap kesehatan mereka. ${ }^{85} \mathrm{Hal}$ ini sesuai dengan teori keperawatan Orem yang menitikberatkan sistem pemeliharaan kesehatan secara mandiri dalam hal ini bagi pasien gagal jantung kongestif. Pencatatan skala sesak nafas yang dilakukan oleh pasien dengan gagal jantung kongestif NYHA II dapat dilakukan secara mandiri, hal ini dimungkinkan sebab pasien dengan NYHA II masih mampu melakukan kegiatan secara mandiri. Reponden penelitian dapat lebih maksimal melakukan self-care pembatasan cairan dengan bantuan dari teknologi kesehatan yaitu pembatasan cairan dan diet sodium. ${ }^{72}$

\section{KESIMPULAN}

Hasil penelitian dan pembahasan pada bab sebelumnya, maka dapat disimpulkan bahwa pengaruh intervensi diet sodium dan pembatasan cairan berbasis aplikasi terhadap keseimbangan cairan dan dyspnea yang dilakukan di Rumah Sakit Umum Daerah Provinsi NTB adalah sebagai berikut:

a. Intervensi diet sodium dan pembatasan cairan berpengaruh pada keseimbangan cairan pasien $C H F$ pada kelompok kontrol dan kelompok intervensi sebelum dan sesudah dilakukan intervensi.

b. Intervensi diet sodium dan pembatasan cairan berpengaruh pada keseimbangan cairan pada pasien $\mathrm{CHF}$

c. Intervensi diet sodium dan pembatasan cairan berpengaruh pada gejala dyspnea pasien $C H F$ pada kelompok kontrol dan kelompok intervensi sebelum dan sesudah dilakukan intervensi.

d. Intervensi diet sodium dan pembatasan cairan berpengaruh pada gejala Dyspnea pada pasien $C H F$

\section{Saran}

1. Instansi pelayanan dapat menyarankan penggunaan aplikasi diet sodium dan pembatasan cairan berbasis android sebagai intervensi monitoring dan edukasi bagi pasien dengan gagal jantung kongestif.

2. Pasien dan keluarga pasien dapat menggunakan aplikasi pembatasan cairan dan diet sodium saat dirumah dalam melakukan managemen kebutuhan cairan.

\section{DAFTAR PUSTAKA}

1. Figueroa MS, Peters JI. Congestive Heart Failure: Diagnosis, Pathophysiology, 
Therapy, and Implications for Respiratory Care. Respir Care 2006; 51: 403-412.

2. Aronow WS. Epidemiology, Pathophysiology, Prognosis, and Treatment of Systolic and Diastolic Heart Failure. Cardiol Rev 2006; 14: 108-124.

3. Aafp. ACCF and AHA Release Guideline on the Management of Heart Failure. 90www.aafp.org/afp (2014).

4. Yancy C. Review of The 2013 Heart Failure Guidelines: What You Need to Know (Part 1). Am Hear Assoc.

5. Heidenreich PA, Trogdon JG, Khavjou OA, et al. Forecasting the future of cardiovascular disease in the United States: A policy statement from the American Heart Association. Circulation 2011; 123: 933944.

6. Riskesdas. Riset Kesehatan Dasar (RIISKESDAS) 2013. Lap Nas 2013 2013; 1.

7. Parrinello G, Greene SJ, Torres D, et al. Water and Sodium in Heart Failure: A Spotlight on Congestion. Heart Fail Rev 2014; 20: 13-24.

8. Badan Penelitian dan Pengembangan Kesehatan. Riset Kesehatan Dasar (RISKESDAS) 2013. Lap Nas 2013 2013; 1384.

9. Dickstein K, Cohen-Solal A, Filippatos G, et al. ESC Guidelines for the diagnosis and treatment of acute and chronic heart failure 2008. Eur Heart J 2008; 29: 2388-2442.

10. Tuy T, Peacock WF. Fluid Overload Assessment and Management in Heart Failure Patients. Semin Nephrol 2012; 32: 112-120.

11. Madjid A. Analisis faktor yang berhubungan dengan kejadian rawat inap ulang pasien gagal jantung kongestif di rumah sakit yogyakarta. Universitas Indonesia, 2010.

12. EFEKTIFITAS DISCHARGE PLANNING TERKONTROL TERHADAP KAPASITAS FUNGSIONAL DAN RAWAT INAP ULANG PASIEN CONGESTIVE HEART FAILURE DI RSUP dr . KARIADI SEMARANG.

13. Cotter G, Metra M, Milo-Cotter O, et al. Fluid overload in acute heart failure - Redistribution and other mechanisms beyond fluid accumulation. Eur J Heart Fail 2008; 10: 165-169.

14. Pazos-López P, Peteiro-Vázquez J, CarcíaCampos A, et al. The causes, consequences, and treatment of left or right heart failure. Vasc Health Risk Manag 2011; 7: 237-254.
15. Oxberry SG, Johnson MJ. Review of the evidence for the management of dyspnoea in people with chronic heart failure. Curr Opin Support Palliat Care 2008; 2: 84-8.

16. Pellicori P, Kaur K, Clark AL. Fluid Management In Patients With Chronic Heart Failure. Card Fail Rev 2015; 1: 90.

Muttaqin A. ASUHAN KEPERAWATAN KLIEN DENGAN GANGGUAN KARDIOVASKULER. 1st ed. Jakarta: Salemba

medika.https://books.google.co.id/books?id= noWFt_QVOUMC\&pg=PR2 \&dq=muttaqin, arif\&hl=id\&sa=X\&ved=0ahUKEwj3sOa7 7SAhUDuo8KHR-

3BEUQ6AEIHTAB $\# \mathrm{v}=$ onepage $\& \mathrm{q}=$ muttaqi $\mathrm{n} \% 2$ Carif $\& \mathrm{f}=$ false (2009).

18. Ridho M, Mag N, Tesis J. Universitas Sumatera Utara. 2012; 5-45.

19. Parrinello G, Torres D, Paterna S. Salt and water imbalance in chronic heart failure. Intern Emerg Med 2011; 6: 29-36.

21. Yancy CW, Jessup M, Bozkurt B, et al. 2016 ACC/AHA/HFSA Focused Update on New Pharmacological Therapy for Heart Failure: An Update of the 2013 ACCF/AHA Guideline for the Management of Heart Failure. Circulation 2016; CIR.0000000000000435.

22. Reddy S, Bahl A, Talwar KK. Congestive heart failure in Indians: how do we improve diagnosis \&amp; management? Indian J Med Res 2010; 132: 549-60.

23. Hummel SL, DeFranco AC, Skorcz S, et al. Recommendation of Low-Salt Diet and Short-term Outcomes in Heart Failure with Preserved Systolic Function. DOI: 10.1016/j.amjmed.2009.04.025.

24. Paterna S, Parrinello G, Cannizzaro S, et al. Medium Term Effects of Different Dosage of Diuretic, Sodium, and Fluid Administration on Neurohormonal and Clinical Outcome in Patients With Recently Compensated Heart Failure. Am J Cardiol 2009; 103: 93-102.

25. Philipson H, Ekman I, Forslund HB, et al. Salt and fluid restriction is effective in patients with chronic heart failure. Eur $J$ Heart Fail 2013; 15: 1304-1310.

26. Ural D, Çavuşoğlu $\mathrm{Y}$, Eren $\mathrm{M}$, et al. Diagnosis and management of acute heart failure. 2015; 6: 860-890.

27. Linharesi JC, Castro RA. Prescribing and Conducting Non-Pharmacological Management of Patients With Decompensated Heart Failure. 2010; 18: 
1145-1152.

28. Hidayati S, Sitorus R. Efektifitas Konseling Analisis Transaksional Tentang Diet Cairan Terhadap Penurunan Interdialytic Weight Gain ( Idwg ).

29. Siswanto BB, Hersunarti N, Erwinarto, et al. Pedoman Tatalaksana Gagal Jantung. Perhimpun Dr Spes Kardiovask Indones; $1 \mathrm{http}: / /$ www.inaheart.org/upload/file/Pedoma n_TataLaksana_Gagal_Jantung_2015.pdf (2015).

30. Self T, Dari C, Dan O, et al. Dalam Praktek Keperawatan. 2010; 97-100.

31. Mia Intania Ramela, Ismonah H. Analisis faktor-faktor yang mempengaruhi kepatuhan pembatasan asupan cairan pada klien dengan chronic kidney disease yang menjalani hemodialisis. 2012; 1-14.

32. Lee Y, Kozar KA, Larsen KRT. The technology acceptance model: Past, present, and future. Commun Assoc Inf Syst 2003; 12: 752-780.

33. Vervloet M, Linn AJ, van Weert JC, et al. The effectiveness of interventions using electronic reminders to improve adherence to chronic medication: a systematic review of the literature. J Am Med Inf Assoc 2012; 19: 696-704.

34. Inamdar A, Inamdar A. Heart Failure: Diagnosis, Management and Utilization. $J$ Clin Med 2016; 5: 62.

35. Black JM, Hawks JH. Medical-surgical nursing: clinical management for positive outcomes. Saunders/Elsevier, 2009.

36. Williams LS (Linda S, Hopper PD. Understanding medical surgical nursinghttp://www.fadavis.com/product/nursi ng-lpn-lvn-understanding-medical-surgicalnursing-med-surg-williams-hopper-5 (accessed 11 May 2017).

37. Brunner LS, Smeltzer SC. textbook of medical-surgical nursing. 12th ed. Philadelphia: Wolters Kluwer Health/Lippincott Williams, 2010.

38. Androne AS, Hryniewicz K, Hudaihed A, et al. Relation of unrecognized hypervolemia in chronic heart failure to clinical status, hemodynamics, and patient outcomes. Am J Cardiol 2004; 93: 1254-1259.

39. Nicholson C. Heart Failure: A Clinical Nursing Handbook. Chisester: Jhon Wiley And Sons, 2007.

40. Heart A. Practice Guidelines. American Heart Association.2015

41. Fisher JD. New York Heart Association
Classification. Arch Intern Med 2014; 129: 836.

42. d'Almeida KSM, Rabelo-Silva ER, Souza GC, et al. Effect of fluid and dietary sodium restriction in the management of patients with heart failure and preserved ejection fraction: study protocol for a randomized controlled trial. Trials 2014; 15: 347.

43. Bhalerao K, Gambhire S. International Research Journal of Pharmaceutical and Applied Sciences ( IRJPAS ). 2013; 3: 224237.

44. Lundell S, Holmner ??sa, Rehn B, et al. Telehealthcare in COPD: A systematic review and meta-analysis on physical outcomes and dyspnea. Respir Med 2015; 109: 11-26.

45. Data Penelitian Tahun 2015 Fakultas Kedokteran

46. Muttaqin A. Pengantar Asuhan Keperawatan Klien dengan Gangguan Sistem Kardiovaskular. III. Jakarta: Salemba medika., 2012.

47. Smeltzer, C.S B. Buku Ajar Keperawatan Medikal Bedah. Jakarta: EGC, 2008.

48. Kebutuhan T. DAFTAR PUSTAKA Wartonah, Tarwoto. 2010. 2010; 2010.

49. Fluid Management Strategies in Heart Failure.: EBSCOhost. 2014; 2014.

50. Claure-Del Granado R, Mehta RL. Fluid overload in the ICU: evaluation and management. BMC Nephrol 2016; 17: 109.

51. Selewski DT, Cornell TT. Continuous Renal Replacement Therapy. 2012; 37: 1166-1173.

52. Ridho M, Mag N, Tesis J. Universitas Sumatera Utara. 2012; 4-18.

53. Buyens J. Web Database Development. Jakarta: Elex Media Komputindo, 2008.

54. Penido MG. Technical Problems in Patients on Hemodialysis. Croatia: InTech, 2011.

55. Simmons L. Dorthea Orem's self care theory as related to nursing practice in hemodialysis. Nephrol Nurs J 2010; 36: 419-421.

56. Crown S, Vogel JA, Hurlock-chorostecki C. of Interdialytic Fluid Weight Gain in Patients on Hemodialysis: A Pilot Study Using Motivational Interviewing. 2017; 44: 49-55.

57. Klien P, Miokardium I, Cvcu DI, et al. (Lavandula Angustifolia).

58. Smith K, Coston M, Glock K, et al. Patient Perspectives on Fluid Management in Chronic Hemodialysis. J Ren Nutr 2011; 20: 334-341.

59. Nerbass FB, Morais JG, dos Santos RG, et al. Adherence and knowledge about 
hyperphosphatemia treatment in hemodialysis patients with hyperphosphatemia. J Bras Nefrol; 32: 14955.

60. Holden RJ, Brown RL, Scanlon MC, et al. Modeling nurses' acceptance of bar coded medication administration technology at a pediatric hospital. J Am Med Informatics Assoc 2012; 19: 1050-1058.

61. Chuttur M. Overview of the Technology Acceptance Model: Origins, Developments and Future Directions. Sprouts Work Pap Inf Syst 2009; 9: 1-23.

62. Park SY. An Analysis of the Technology Acceptance Model in Understanding University Students' Behavioral Intention to Use e-Learning. Educ Technol Soc 2009; 12: 150-162.

63. Dharma KK. Metodologi Penelitian Keperawatan: Pedoman Melaksanakan dan Menerapkan Hasil Penelitian. Jakarta: Trans Info Media, 2011.

64. Arikunto, S. Prosedur Penelitian. Suatu Pendekatan Praktek. Jakarta: Raneka Cipta., 2002.

65. Nursalam. Konsep dan Penerapan Metodologi Ilmu Keperawatan. Jakarta.: : Salemba Medika., 2008.

66. Sastroasmoro S IS. Dasar-dasar Metodologi Penelitian Klinis. Edisi ke-5. Jakarta: CV, Agung Seto., 2014.

67. Sastroasmoro S. Dasar-Dasar Metodologi Penelitian Klinis. 3rd ed. Jakarta: CV Sagung Seto, 2010.

68. Denise F. Polite. Nursing Research, Principles and Methods. 7th ed. Philadepphia: Lippincott Williams and Wilkins, 2004.

69. Dahlan MS. Besar Sampel dan Cara Pengambilan Sampel dalam Penelitian Kedokteran dan Kesehatan. Jakarta.: Salemba medika., 2013.

70. Hsu K, Lin J, Lin M, et al. The modified Medical Research Council dyspnoea scale is a good indicator of health-related quality of life in patients with chronic obstructive pulmonary disease. 2013 ; 54: 321-327. 